\title{
Vasorelaxation endothelium-independent of the ethyl acetate phase from aerial parts of Solanum paludosum Moric. envolves channels-calcium L-type blockade
}

\author{
Vasorrelaxamento independente de endotélio da fase acetato de etilla obtida das partes aéreas de \\ Solanum paludosum Moric. envolve bloqueio de canais de cálcio do tipo $\mathrm{L}$ \\ Vasorrelajación independiente del endotelio de la fase de acetato de etilo obtenida de las partes \\ aéreas de Solanum paludosum Moric. implica bloquear los canales de calcio de tipo L
}

\author{
Joelmir Lucena Veiga da Silva \\ ORCID: https://orcid.org/0000-0001-5722-0213 \\ Faculdade de Medicina de Olinda, Brazil \\ E-mail: joelmirluce@ hotmail.com \\ Fabiana de Andrade Cavalcante \\ ORCID: https://orcid.org/0000-0002-5462-9459 \\ Universidade Federal da Paraíba, Brazil \\ E-mail: fa_cavalcante@ hotmail.com \\ Tania Maria Sarmento da Silva \\ ORCID: https://orcid.org/0000-0003-1887-2598 \\ Universidade Federal Rural de Pernambuco, Brazil \\ E-mail: taniasarmento@dq.ufrpe.br \\ Alessandro Elery Ramos \\ ORCID: https://orcid.org/0000-0001-6505-3320 \\ Hospital Santa Isabel, Brazil \\ E-mail: barcuk.3@hotmail.com \\ Thárcia Kiara Beserra Oliveira \\ ORCID: https://orcid.org/0000-0001-6352-7254 \\ Faculdade de Medicina de Olinda, Brazil \\ E-mail: tharcia_kiara@hotmail.com \\ Schirley Cristina Almeida Pereira \\ ORCID: https://orcid.org/0000-0002-2837-689X \\ Faculdade de Medicina de Olinda, Brazil \\ E-mail: schirleyscap@hotmail.com \\ Bagnólia Araújo da Silva \\ ORCID: https://orcid.org/0000-0001-6926-482X \\ Universidade Federal da Paraíba, Brazil \\ E-mail: bagnoliasilva@yahoo.com.br
}

\begin{abstract}
Previous results showed the ethyl acetate phase (SP-AcOEt), obtained from aerial parts of Solanum paludosum, relaxed the aorta isolated in the endothelium-dependent and -independent manner. The vasorelaxant effects of SPAcOEt was not characterized on aorta rings endothelium-denuded, thus this work aimed to elucidate the mechanisms endothelium-independent vasorelaxation on rat isolated aorta. The aorta was isolated from Wistar rats and mounted in glass baths containing $6 \mathrm{~mL}$ of normal Krebs physiological solution with $\mathrm{pH}$ at 7.4. The preparation was maintained at $37^{\circ} \mathrm{C}$ and bubbled continuously with a mixture of $95 \% \mathrm{O}_{2}$ and $5 \% \mathrm{CO}_{2}$. Aortic rings were maintained for 1 hour by a resting tension of $1 \mathrm{~g}$ and next were contracted with phenylephrine after the sustained contraction ACh was added to access the integrity of the endothelium. SP-AcOEt relaxed pre-contracted aorta by KCl-30mM or $-80 \mathrm{mM}$ in a similar manner, suggesting blockade $\mathrm{Ca}_{\mathrm{v}}$, but not channel-K $\mathrm{K}^{+}$participating. SP-AcOEt also inhibited the contraction induced by $\mathrm{CaCl}_{2}$ and relaxed pre-contracted aorta by $( \pm)$-BayK8644 $\left(\mathrm{EC}_{50}=16.9 \pm 1.3 \mu \mathrm{g} / \mathrm{mL}\right)$, which confirms the involvement of L-type $\mathrm{Ca}_{\mathrm{v}}$ blockade. SP-AcOEt presented vasorelaxation endothelium-independent that involves Ltype Cav blockade.
\end{abstract}

Keywords: Medicinal plant; Solanaceae; Vascular smooth muscle; L-type calcium channels.

\section{Resumo}

Resultados anteriores mostraram que a fase acetato de etila (SP-AcOEt), obtida das partes aéreas de Solanum paludosum, relaxou a aorta isolada de maneira dependente e independente de endotélio. Os efeitos vasorrelaxantes de SP-AcOEt não foram caracterizados nos anéis de aorta sem endotélio, assim este trabalho objetivou elucidar os mecanismos vasorrelaxantes independentes de endotélio em aorta isolada de rato. As aortas foram isoladas de ratos 
Wistar e montadas em cubas de vidro para órgão isolado contendo $6 \mathrm{~mL}$ de solução fisiológica de Krebs com pH 7,4. A preparação era mantida a $37^{\circ} \mathrm{C}$ e aerada continuamente com carbogênio. Os anéis de aorta foram mantidos em estabilização por $1 \mathrm{~h}$, sob tensão de repouso de $1 \mathrm{~g}$, e depois foram pré-contraídos com fenilefrina seguido de ACh, após uma contração sustentada, para observar a integridade do endotélio funcional. A fase SP-AcOEt relaxou a aorta pré-contraída com KCl-30 e KCl-80mM de maneira similar, sugerindo o bloqueio de $\mathrm{Ca}_{\mathrm{V}}$, mas não a participação de canais- $\mathrm{K}^{+}$. SP-AcOEt também inibiu as contrações induzidas por $\mathrm{CaCl}_{2}$, meio alto $\mathrm{K}^{+}$e sem cálcio, e relaxou a aorta pré-contraída com ( \pm )-BayK8644 $\left(\mathrm{CE}_{50}=16,9 \pm 1,3 \mu \mathrm{g} / \mathrm{mL}\right)$, confirmando o envolvimento do boqueio de Ca $\mathrm{V}_{\mathrm{V}}$ do tipoL. A fase SP-AcOEt mostrou vasorrelaxamento independente de endotélio que envolve o bloqueio de Cav do tipo-L.

Palavras-chave: Planta medicinal; Solanaceae; Músculo liso vascular; Canais de cálcio do tipo L.

\section{Resumen}

Resultados anteriores demostraron que la fase de acetato de etilo (SP-AcOEt), obtenida de las partes aéreas de Solanum paludosum, relajó la aorta aislada de forma dependiente e independiente del endotelio. Los efectos vasorrelajantes de SP-AcOEt no se caracterizaron en anillos aórticos sin endotelio, por lo que este trabajo tuvo como objetivo dilucidar los mecanismos de vasorrelajación independientes del endotelio en aorta aislada de rata. Las aortas se aislaron de ratas Wistar y se montaron en viales de vidrio para un órgano aislado que contenía 6 ml de solución salina de Krebs con pH 7,4. La preparación se mantuvo a $37^{\circ} \mathrm{C}$ y se aireó continuamente con carbogen. Los anillos aórticos se mantuvieron estabilizados durante 1 h, bajo una tensión de reposo de 1 gy luego se precontrataron con Fen seguido de ACh, después de una contracción sostenida, para observar la integridad del endotelio funcional. La fase SP-AcOEt relajó la aorta precontraída con $\mathrm{KCl}-30$ y $\mathrm{KCl}-80 \mathrm{mM}$ de manera similar, lo que sugiere bloqueo de Cav, pero no la participación de canales de $\mathrm{K}^{+}$. SP-AcOEt también inhibió las contracciones inducidas por $\mathrm{CaCl}_{2}, \mathrm{medio}^{+}$ y sin calcio, y relajó la aorta precontraída con $( \pm)$-BayK8644 $\left(\mathrm{EC}_{50}=16,9 \pm 1,3 \mu \mathrm{g} / \mathrm{mL}\right)$, confirmando la afectación del bloqueo Cav tipo L. La fase SP-AcOEt mostró vasorrelajación independiente del endotelio que involucra bloqueo de Cav tipo L.

Palabras clave: Planta medicinal; Solanaceae; Músculo liso vascular; Canais de cálcio do tipo L.

\section{Introduction}

The cardiovascular diseases have been the main causes of death, hospitalization and outpatient care in the world, including developing countries, as such Brazil (GBD, 2016). The medicinal plants are used, mainly, to treat hypertension (Zago et al., 2020). Thus, the researching for newer treatments is an ongoing process and plants may be a significant source of medicines.

Solanum paludosum Moric. (Solanaceae) is an herbaceous species, called "todomaka" in Surinam and "jurubeba", “jurubeba-roxa” or "jurubeba-brava” in Brazil. The fruits from Solanum paludosum showed molluscicidal activity (Silva et al., 2005), the root bark has been reported hemolytic activity on erythrocytes of rats and displayed spasmolytic activity on rat uterus and guinea-pig trachea (Riet-Correa et al., 2011) and vasorelaxant action (Monteiro et al., 2012). The aerial parts presented antioxidant and antibacterial activity (Siqueira et al., 2011).

Chemical studies resulted in the isolating of flavonoids (genkwanin, kumatakenin, ramnocitrin, protocatechuic acid, 3,4',7,8-tetramethyl gossypetin ether, 3,3',4'7,8-pentamethyl gossypetin ether, retusin, 3-methyl quercetin ether) and an alkamide (N-p-coumaroyltyramine) from the aerial parts (Silva et al., 2002). The total alkaloid fraction from root bark showed the identification N-hydroxysolasodine, leptinidine, tomatidenol and putuline (Bhattacharyya et al., 2009).

Previous result our showed SP-AcOEt presents endothelium-dependent and independent vasorelaxation. Therefore, we investigated the endothelium-independent vasorelaxation mechanisms of the SP-AcOEt obtained from aerial parts of Solanum paludosum on rat aorta.

\section{Methodology}

This research is quantitative and experimental (Pereira et al., 2018), preclinical (Oliveira et al, 2019). All experiments are submitted and approved by Animal Experimentation Ethical Committee (CEPA) of Universidade Federal da Paraíba. 


\subsection{Plant material and extraction}

The isolating was performed by Silva et al. (2002). Briefly, the aerial parts of the plant were collected in Brazil, State of Paraíba, municipality of João Pessoa, in summer of January 1999. Voucher specimens (M.F. Agra et al. 5257) are deposited at the Herbarium by Prof. Lauro Pires Xavier (JPB), Universidade Federal da Paraíba. The powdered aerial parts of Solanum paludosum were extracted with EtOH at room temperature. The extract was concentrated under vacuum. The crude residue was dissolved in $\mathrm{H}_{2} \mathrm{O} / \mathrm{AcOH}$ (8:2) and extracted with benzene/ether (1:1). These solvents were removed, the residue was dissolved in $\mathrm{MeOH} / \mathrm{H}_{2} \mathrm{O}(8: 2)$ and extracted with hexane (3x) and then with AcOEt (3x), obtained the AcOEt phase (SPAcOEt).

\subsection{Preparation of rat aorta rings}

Male Wistar rats (Rattus novergicus) weighting 200-350 g were euthanized by cerebral concussion. The aorta was cut into rings with width of about 3-5 mm in width and mounted in glass baths containing $6 \mathrm{~mL}$ of normal Krebs physiological solution with the following composition (mM): $\mathrm{NaCl} 118.0, \mathrm{KCl}$ 4.6, $\mathrm{CaCl}_{2} .2 \mathrm{H}_{2} \mathrm{O}$ 2.5, $\mathrm{KH}_{2} \mathrm{PO}_{4}$ 1.1, $\mathrm{MgSO}_{4}$ 5.7, glucose 11.0, $\mathrm{NaHCO}_{3}$ 25.0. The $\mathrm{pH}$ was adjusted at 7.4. The nutritive solution was maintained at $37^{\circ} \mathrm{C}$ and bubbled continuously with a mixture of $95 \% \mathrm{O}_{2}$ and 5\% $\mathrm{CO}_{2}$. Each ring had two metallic hooks inserted through the lumen; one was anchored to the glass bath and the other was attached to an isometric force transducer (FORT-10) connected to an amplifier (TBM-4M). Both equipaments are from World Precision Instruments (EUA) and are coupled to a data-acquisition system BioMed (BioData, Brazil) for recording isometric contractile response. Aortic rings were maintained for 1 hour by a resting tension of $1 \mathrm{~g}$ and rinsed 4 times with Krebs solution. Followed, aortic rings were contracted with Phe $(0.3 \mu \mathrm{M})$ after the sustained contraction ACh $(1 \mu \mathrm{M})$ was added to access the integrity of the endothelium (Furchgot \& Zawadki, 1980). The rings with more than 50\% relaxation to ACh were considered to be endothelium-functional (Ajay et al., 2003).

\subsection{Characterization of the endothelium-independent vasorelaxation mechanism}

In order to investigate the endothelium-independent mechanism involving the vasorelaxation of SP-AcOEt, we used aorta rings without functional endothelium. To observe whether $\mathrm{K}^{+}$-channel or $\mathrm{CaV}$-channels were involved in relaxant response, we accessed the effects of SP-AcOEt on contraction induced by high $\mathrm{K}^{+}$solution $(\mathrm{KCl}-30$ or $-80 \mathrm{mM}$ ). Concentration-response curves were plotted as \% relaxation against logarithmic concentration of plant products and the concentration producing a half-maximal response $\left(\mathrm{EC}_{50}\right)$ values were calculated by non-linear regression. To confirm the involvement of $\mathrm{Ca}_{\mathrm{v}}$-channels, contractions induced by $\mathrm{Ca}^{+2}$ were stimulated gradually by adding $\mathrm{CaCl}_{2}\left(10^{-7}-10^{-1} \mathrm{M}\right)$ to the high $\mathrm{K}^{+}$Krebs solution without $\mathrm{Ca}^{2+}$, as a control reference. After the aorta rings were washed three times, during 30 minutes, with high-K $\mathrm{K}^{+}$Krebs solution without $\mathrm{Ca}^{2+}$, the addition of SP-AcOEt $(9 ; 27$ and $81 \mu \mathrm{g} / \mathrm{mL})$ to the glass bath followed 15 minutes the cumulative $\mathrm{Ca}^{2+}$-induced contractions were repeated. Once again, the effects of SP-AcOEt and flavonoids on $( \pm)$ BayK8644-(0.3 $\mu \mathrm{M})$ induced contractions (on dimmer light) were observed (Schramm et al., 1983). The contraction rate was expressed as a percentage of the maximum tension obtained in the control reference.

\subsection{Drugs}

The followings drugs were used: ACh (Merck, Brazil); Phe (Pfizer, USA); cremofor (Sigma-Aldrich, USA); \pm )BayK8644 (Research Biochemicals International, USA); $( \pm$ )-BayK8644 was prepared as stock solution in methanol (on dimmer light). The SP-AcOEt phase was prepared as stock solution in 3\% cremofor. 


\subsection{Statistical analysis}

All results were expressed as mean \pm SEM and were statistically analyzed using the T-test or ANOVA following Bonferroni's test. In all cases, statistical differences were considered significant only if the 'P' value was less than 0.05 $(<0.05)$. The responses were computer-fitted to a sigmoid curve using non-linear regression (GraphPad Prism version 3.02, USA.) and $\mathrm{EC}_{50}$ were calculated.

\section{Results and Discussion}

The SP-AcOEt relaxed the pre-contracted aorta rings by $\mathrm{KCl} 30-\left(\mathrm{EC}_{50}=20.6 \pm 4.9 \mu \mathrm{g} / \mathrm{mL}\right)$ and $\mathrm{KCl} 80 \mathrm{mM}-\left(\mathrm{EC}_{50}=\right.$ $17.4 \pm 3.6 \mu \mathrm{g} / \mathrm{mL}$ ) in a similar manner (Figure 1), indicating a blockade of $\mathrm{Ca}^{2+}$ influx through Cav-channels (Gurney, 1994). The SP-AcOEt was five times more potent to relax $\mathrm{KCl}-80$ than rings were pre-contracted with phenylephrine (data not shown). Those results match the ones reported by Sakata \& Karaki (1991) in vascular smooth muscle, which demonstrated blockade of $\mathrm{Cav}$-channels are more potent for relaxing response on high- $\mathrm{K}^{+}$than norephinephrine. Therefore, all these results indicate the vasorelaxant action of SP-AcOEt could be due to blockade $\mathrm{Ca}^{2+}$-influx through $\mathrm{Ca}_{\mathrm{v}}$-channels.

Figure 1. Effects of SP-AcOEt on aorta rings pre-contracted by $\mathrm{KCl}-30 \mathrm{mM}(\triangle)$ or $-80 \mathrm{mM}(\mathbf{\Delta})(\mathrm{n}=5)$.

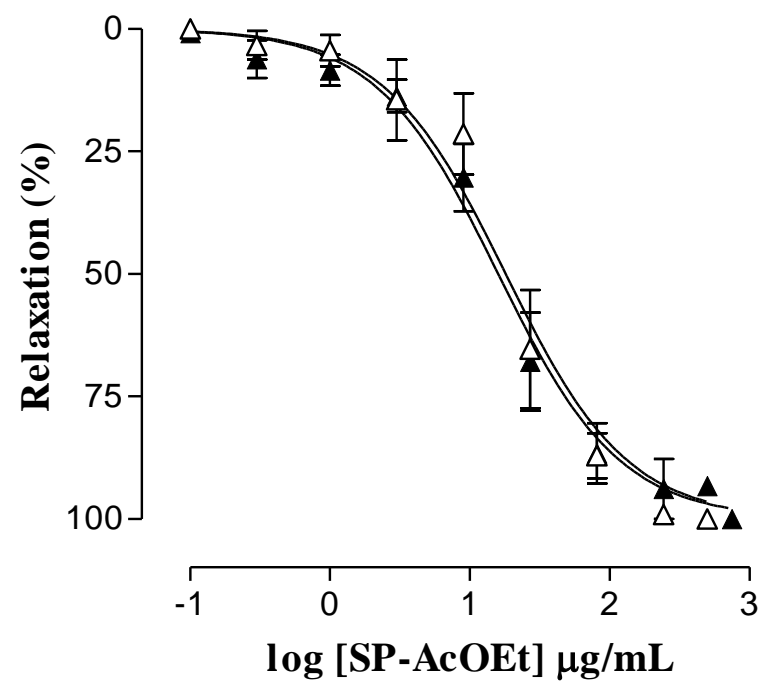

Source: Authors (2021).

Channels- $\mathrm{Ca}^{2+}$ represent the main route for $\mathrm{Ca}^{2+}$ translocation across the plasma membrane and support several functions, including muscle contraction (Fusi et al., 2017). Although various families channels-Ca ${ }^{2+}$ are expressed in

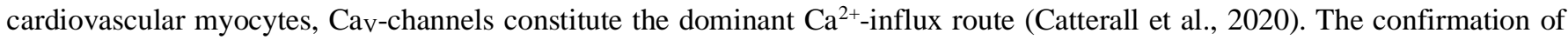
Cav-channels blockade by SP-AcOEt $(9 ; 27$ or $81 \mu \mathrm{g} / \mathrm{mL})$ was observed in the inhibition curves induced by $\mathrm{CaCl}_{2}$ in high- $\mathrm{K}^{+}$ and without $\mathrm{Ca}^{2+} \mathrm{Krebs}$. The curves induced by $\mathrm{CaCl}_{2}$ were right shifted in a non-parallel manner and decreased the maximal effect $\left(\mathrm{E}_{\max }=78.7 \pm 5.5 ; 52.3 \pm 8.3 ; 22.6 \pm 5.6 \%\right.$, respectively) (Figure 2). The fraction of total flavonoids of Elsholtzia splendens inhibited also $\mathrm{Ca}^{2+}$-induced contraction in endothelium-denuded aortic rings (Wang et al., 2014). 
Figure 2. Concentration-response curves to $\mathrm{CaCl}_{2}$ in high- $\mathrm{K}^{+} \mathrm{Krebs}$ solution without $\mathrm{Ca}^{2+}$ in aorta rings without functional endothelium $(\mathrm{n}=5)$.

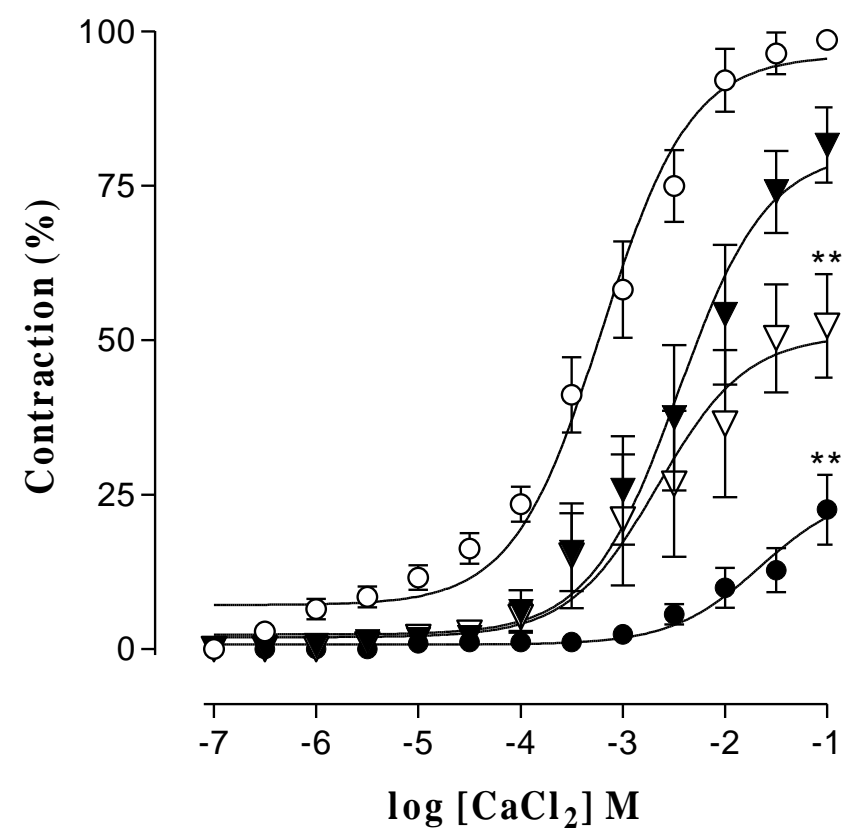

Being: control $(\mathrm{O})$; presence of $9(\boldsymbol{\nabla}), 27(\nabla)$ or $81(\bullet) \mu \mathrm{g} / \mathrm{mL}$ of SP-AcOEt. $* * P<0.001$, One-way ANOVA following of Bonferroni’s test (control vs. SP-AcOEt).

Source: Authors (2021).

Another evidence was that SP-AcOEt $\left(\mathrm{EC}_{50}=16.9 \pm 1.3 \mu \mathrm{g} / \mathrm{mL}\right)$ relaxed pre-contracted rings by $( \pm)$-BayK8644 (Fig. 3), an activator of L-type $\mathrm{Ca}_{\mathrm{v}}$-channels (Schramm et al., 1983), and the $\mathrm{EC}_{50}$ value did not show a significant difference compared to $\mathrm{KCl}-80 \mathrm{mM}$. L-type $\mathrm{Ca}_{\mathrm{v}}$-channels have long been considered the primary route of $\mathrm{Ca}^{2+}$ entry in vascular smooth muscle (Ghosh et al., 2017). Thus, all data strongly corroborate the involvement of L-type Cav-channels blockade in this endothelium-denuded vasorelaxant mechanism of SP-AcOEt. 
Figure 3. Effects of SP-AcOEt on pre-contracted aorta rings by $( \pm)$-Bay $\mathrm{K} 8644(0.3 \mu \mathrm{M})$ in the absence of functional endothelium $(\mathrm{n}=5)$.
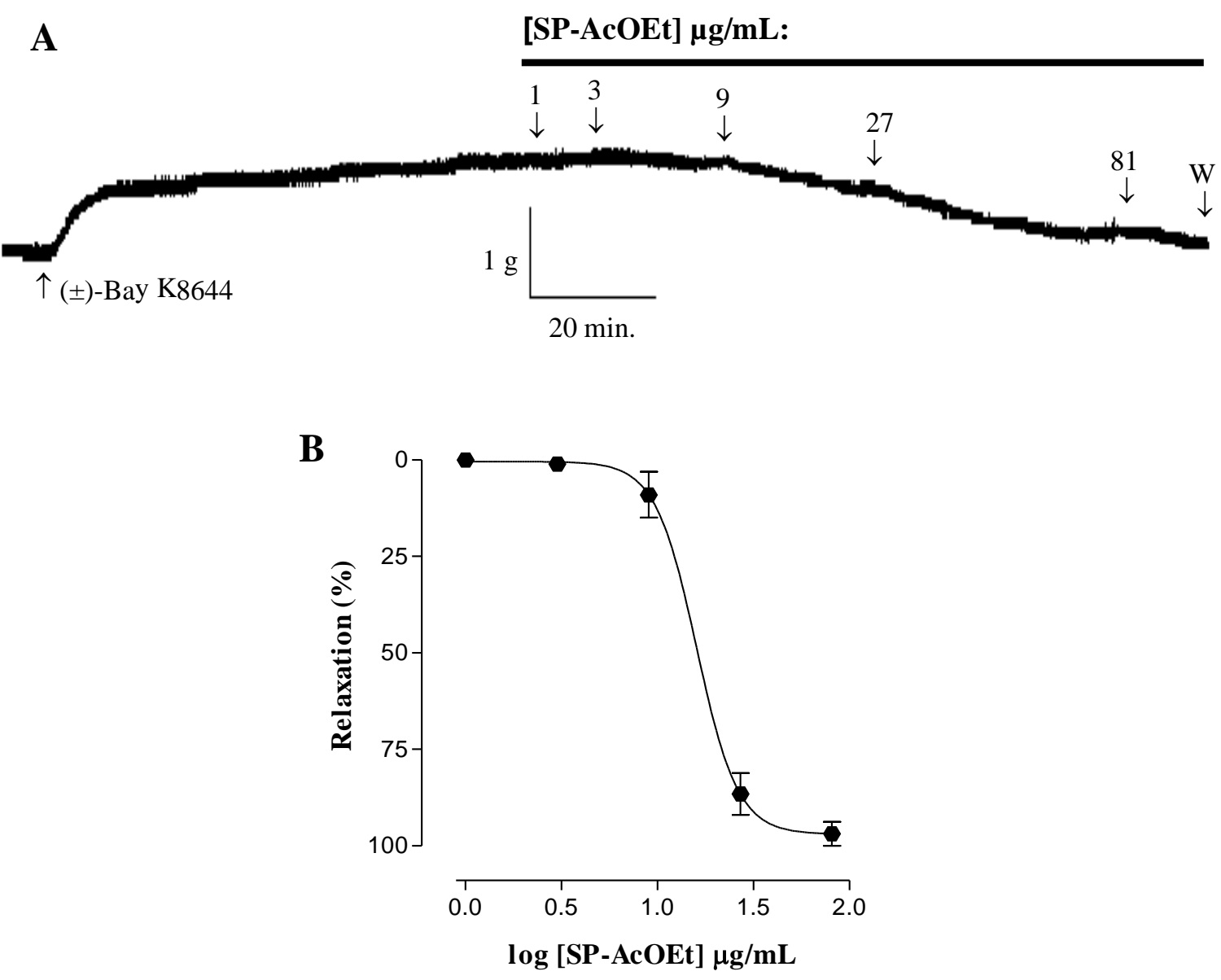

Being: A: selected sample of original tracing shows SP-AcOEt-induced relaxation; B: graphic of SP-AcOEt on pre-contracted aorta rings. W = wash.

Source: Authors (2021).

The chemical analyses from SP-AcOEt showed flavonoids and alkamide (Silva et al., 2002), maybe those flavonoids had induced blockade the $\mathrm{Ca}_{\mathrm{v}}$-channels. Because flavonoids and phenol compounds have been presented inhibiting contractions on smooth and cardiac muscles by Cav-channels blockade (Vourela et al., 1997; Penso et al., 2014; Fusi et al., 2017) and flavones inhibited contractions induced by $\mathrm{Ca}^{2+}$ (Lin et al., 1997; De Rojas et al., 1999; Tew et al., 2020; Migkos et al., 2020). The calcium-blockers decrease $\mathrm{Ca}^{2+}-$ level on vascular smooth muscle, resulting vascular tonus relaxation and decreasing blood pressure (Kochegarov, 2003), and are include medicines, frequently, prescribe for treatment of hypertension (Brașoveanu et al., 2019).

\section{Conclusion}

The results of the present study make us to conclude the phase SP-AcOEt from aerial parts of Solanum paludosum presents vasorelaxation endothelium-independent that involves, mainly, blockade of L-type channels-Cav.

In the future, it is intended to determine whether isolated flavonoids promote those vasorelaxation effects and to design its molecular docking. 


\section{Acknowledgments}

This study would like to acknowledge Conselho Nacional de Desenvolvimento Científico e Tecnológico (CNPq) and Coordenação de Aperfeiçoamento de Pessoal de Nível Superior (CAPES) for the financial support.

\section{References}

Ajay, M., Gilani, A. H. \& Mustafaa, M. R. (2003) Effects of flavonoids on vascular smooth muscle of the isolated rat thoracic aorta. Life Science, 74(5), 603612.

Bhattacharyya, J., Basilio, I. J. L. D., Morais, L. C. S. L., Agra, M. F. \& Majetich G. (2009). Alkaloids of the root-bark of Solanum paludosum Moric. Biochemical Systematics and Ecology, 37, 228-229.

Catterall, W. A., Lenaeus, M. J. \& Gamal El-Din, T. M. (2020). Structure and Pharmacology of Voltage-Gated Sodium and Calcium Channels. Annual Review of Pharmacology and Toxicology, 60, 133-154.

De Rojas, V. R. S., Somoza, B., Ortega, T., Villar, A. M. \& Tejerina, R. (1999). Vasodilatory effect in rat aorta of eriodictyol obtained from Satureja obovata. Planta Medica, 65(3), 234-238.

Furchgott, R. F. \& Zawadki, J. V. (1980). The obligatory role of endothelium cells in the relaxation of arterial smooth muscle by acetylcholine. Nature, 288(5789), 373-376.

Fusi, F., Spiga, O., Trezza, A., Sgaragli, G. \& Saponara S. (2017). The surge of flavonoids as novel, fine regulators of cardiovascular Cav channels. European Journal of Pharmacology, 796, 158-174.

GBD 2016 Causes of Death Collaborators. Global, regional, and national age-sex specific mortality for 264 causes of death, 1980- 2016: a systematic analysis for the Global Burden of Disease Study. (2017). Lancet, 390(10100), 1151-210.

Ghosh, D., Syed, A. U., Prada, M. P., Nystoriak, M. A., Santana, L. F., Nieves-Cintrón M. \& Navedo, M. F. (2017). Calcium Channels in Vascular Smooth Muscle. Advances in Pharmacology, 78, 49-87.

Gurney, A. M. (1994). Mechanisms of drug-induced vasodilation. Journal of Pharmacy and Pharmacology, 46(4), $242-251$.

Kochegarov, A. A. (2003). Pharmacological modulators of voltage-gated calcium channels and their therapeutical application. Cell Calcium, 33(3), 145-162.

Lin, C. N., Kuo, S. H., Chung, M. I., Ko, F. N. \& Teng, C. M. (1997). A new flavone c-glycoside and antiplatelet and vasorelaxing flavones from Gentiana arisanensis. Journal of Natural Products, 60(8), 851-853.

Migkos, T., Pourová, J., Vopršalová, M., Auger, C., Schini-Kerth, V. \& Mladěnka, P. (2020). Biochanin A, the Most Potent of 16 Isoflavones, Induces Relaxation of the Coronary Artery Through the Calcium Channel and cGMP-dependent Pathway. Planta Medica, 86(10), 708-716.

Monteiro, F. S., Silva, A. C. L., Martins, I. R. R., Correia, A. C. C., Basílio, I. J. L. D., Agra, M. F., Bhattacharyya, J. \& Silva, B. A. (2012). Vasorelaxant action of the total alkaloid fraction obtained from Solanum paludosum Moric. (Solanaceae) involves NO/cGMP/PKG pathway and potassium channels. Journal of Ethnopharmacology, 141, 895-900.

Oliveira, T. K. B., Silva-Júnior, P. R. \& Andrade-Filho, J. A. (2019). Modelos experimentais: pesquisa com animais de laboratório [recurso eletrônico]. Aracaju: IFS.

Penso, J., Cordeiro, K. C. F. A., Cunha, C. R. M., Castro, P. F. S., Martins, D. R., Lião, L. M., Rocha, M. L. \& Oliveira, V. (2014). Vasorelaxantactivityof7-3O-glycosides biosynthesized from flavonoids. European Journal of Pharmacology, 733, 75-80.

Pereira, A. S., Shitsuka, D. M., Parreira, F. J. \& Shitsuka, R. (2018). Metodologia da pesquisa cientifica UFSM, NTE.

Riet-Correa, F., Pfister, J., Schild, A. L. \& Wierenga, T. (2011). Poisoning by Plants, Mycotoxins and Related Toxins. CAB Internacional.

Sakata, K., \& Karaki, H. (1991). Effects of a novel smooth muscle relaxant, KT-362, on contraction and cytosolic Ca ${ }^{2+}$ level in the rat aorta. British Journal of Pharmacology, 102(1), 174-178.

Schmidt, M. I., Duncan, B. B., Azevedo-Silva, G., Menezes, A. M., Monteiro, C. A., Barreto, S. M., et al. (2011). Chronic non-communicable diseases in Brazil: burden and current challenges. Lancet, 377, 1949-1961.

Schramm, M., Thomas, G., Towart, R. \& Franckowiak, G. (1983). Novel dihydropyridines with positive inotropic action through activation of Ca ${ }^{2+}$ channels. Nature, 303(5917), 535-537.

Silva, T. M. S., Batista, M. M., Camara, C. A. \& Agra, M. F. (2005). Molluscicidal activity of some Brazilian Solanum spp. (Solanaceae) against Biomphalaria glabrata. Annals of Tropical Medicine and Parasitology, 99(4), 1-7.

Silva, T. M. S., Braz-Filho, R., Carvalho, M. G., Agra, M. F. (2002). Flavonoids and alkamide from Solanum paludosum Moric. Biochemical Systematics and Ecology, 30, 479-481.

Siqueira, S., Falcão-Silva, V. S., Agra, M. F., Dariva, C., Siqueira-Júnior, J. P. \& Fonseca, M. J. V. (2011). Biological activities of Solanum paludosum Moric. extracts obtained by maceration and supercritical fluid extraction. The Journal of Supercritical Fluids, 58, $391-397$. 
Research, Society and Development, v. 10, n. 1, e31710111845, 2021 (CC BY 4.0) | ISSN 2525-3409 | DOI: http://dx.doi.org/10.33448/rsd-v10i1.11845

Tew, W. Y., Tan, C. S., Asmawi, M. Z., \& Yam, M. F. (2020). Underlying mechanism of vasorelaxant effect exerted by 3,5,7,2',4'-pentahydroxyflavone in rats aortic ring. European Journal of Pharmacology, 880, 173123.

Vuorela, H., Vuorela, P., Törnquist, K., \& Alaranta, S. (1997). Calcium channel blocking activity: screening methods for plant derived compounds. Phytomedicine, 4(2), 167-180.

Wang, H. P., Lu, J. F., Zhang, G. L., Li, X. Y., Peng H. Y., Lu, Y., Zhao, L., Ye, Z. G., Bruce, I. C., Xia, Q., \& Qian, L. B. (2014). Endothelium-dependent and -independent vasorelaxant actions and mechanisms induced bytotal flavonoids of Elsholtzia splendens in rat aortas. Environmental Toxicology and Pharmacology, 38(2), 453-9.

Zago, P. M. J. J., Meotti, F. L., Iukava, L. K., Coradette, C. D. D. S., Oterio, J., Zardeto-Sabec, G., \& Boleta-Ceranto, D. D. C. F. (2020). Percepção dos pacientes de um consultório de cardiologia acerca da utilização de plantas medicinais no tratamento da hipertensão arterial. Research, Society and Development, 9(11), e78791110312. 